\title{
Assessment of Nutritional Requirement for Food Security in Tropical Islands of India
}

\author{
B. K. $\operatorname{Nanda}^{1 *}$, N. Sahoo ${ }^{2}$ and B. Panigrahi ${ }^{2}$ \\ ${ }^{1}$ (Ag Engg), ICAR-KVK, Port Blair, India \\ ${ }^{2}$ Department of Soil and Water Conservation Engineering, CAET, OUAT, Bhubaneswar, India \\ *Corresponding author
}

\section{A B S T R A C T}

\begin{tabular}{l} 
K e y w o r d s \\
Food security, \\
Nutritional \\
requirement, \\
Recommended \\
dietary allowances, \\
Tropical islands \\
\hline Article Info \\
\hline $\begin{array}{l}\text { Accepted: } \\
\text { 10 March } 2020 \\
\text { Available Online: } \\
\text { 10 April } 2020\end{array}$ \\
\hline
\end{tabular}

The annual food requirement for the projected population for the year 2021 for the tropical South Andaman group of islands was estimated as per guidelines of recommended dietary allowance (RDA). The values suggested are the requirement of 73,750 tonnes of cereals, 16,506 tonnes of pulses, 14,176 tonnes of oil seeds and 54,499 tonnes of vegetables and tubers. The present cropping pattern of the district has a cultivated area of 271.1 ha for cereals (216.1 ha for rice and 55.0 ha for maize), 14.2 ha for pulses (7.2, 6.5 and 0.5 ha for green gram, black gram and arhar respectively), 2.0 ha for oilseeds (1.2 ha for ground nut and 0.8 ha for mustard) and 1460.5 ha for vegetables and tubers (1317.0, 51.5, 46.0, 26.5 and 19.5 ha for vegetables, ginger, sweet potato, tapioca and turmeric respectively) with a total field crop area of 1747.8 ha. As per the present crop productivity and production in these islands, it is nearly impossible to meet the nutritional requirement of the projected population in the year 2021. These informations will help the planners and other stakeholders to have a viable strategy for effective crop planning with judicious use of available land and water resources to achieve food security in these tropical islands.

\section{Introduction}

The total food grain production in India has gone up from 50 MT in 1950 to 283.37 MT in 2018-19. Today India produces 115.63 MT of rice, 101.20 MT of wheat and 43.33 MT of coarse grains and 23.22 MT of pulses (Government of India, 2018-19). The requirement of annual food grain of India is estimated as 450 million tonnes by the year
2050 (Patel and Rajput, 2015). The demandsupply scenarios present an alarming situation (Ray and Bhattacharyya (2018).

To meet the food security and nutritional needs of the projected population in 2050 , the food production will have to be almost doubled. Management of land and water, may help in savings of significant amounts of water and increase the quality and quantity of 
food grain production. In our country, 53\% of total food grain production comes from kharif season as compared to rabi season where the production is around 47\% (Maurya et al., 2016). The constraint for food grain production during kharif is soil moisture as influenced by the seasonal rainfall from South West monsoon, but in rabi season, the constraint for food grain production is minimum temperature and less quantum of stored soil moisture.

Seasonal rainfall accounts for more than $50 \%$ of the food grain production in our country (Kumar et al., 2004). Variations in the monsoon rainfall affect the total food grain production and also the country's economy, which largely depends on agriculture. Yearto-year fluctuations in summer monsoon rainfall have a strong impact on the variability of aggregate kharif food grain production (Parthasarathy et al., 1992, Gadgil, 1996, Webster et al., 1998). Years with deficient and excess monsoon rainfall are associated with low and high production of food grain, respectively.

But, the negative impact of deficit rainfall is larger than the positive impact of good rainfall (Gadgil and Rupa Kumar, 2006). On this context of dependence of food grain production on climate variability, total food grain requirement for a region is need to be pre estimated for optimal crop planning. The effect of climate on crop production is more pronounced in tropical islands of our countries due to uncertainty of rainfall in crop growing season.

In this study, an attempt has been made to estimate the total food grain production for South Andaman district to sustain food security for the year 2021 so that planners and other stakeholders can formulate an effective crop planning for the area.

\section{Materials and Methods}

\section{Study area}

South Andaman district is a group of 10 inhabited islands situated in southern part of Andaman and Nicobar group of islands and lies between latitudes of $6^{\circ} 45^{\prime} \mathrm{N}$ to $13^{\circ} 4^{\prime} \mathrm{N}$ and longitudes of $92^{\circ} 15^{\prime} \mathrm{E}$ to $94^{\circ} \mathrm{E}$ at an elevation of $13.0 \mathrm{~m}$ from mean sea level. The district comprises of 3 nos. of tehsils and 99 revenue villages and is spreaded in an area of 310.6 thousand ha in Bay of Bengal.

The annual normal rainfall in the district is $3054.2 \mathrm{~mm}$ distributed over 131.1 rainy days (Nanda et al., 2018b). The daily rainfall data since last 30 years (1987-2017) indicates that these groups of islands receive $72.5 \%$ of the total normal rainfall due to South-West monsoon recorded in 91 rainy days (ICARCIARI, 2017; ICAR- KVK, 2018). May to November is the usual wet period, where $90.4 \%$ rainfall is recorded in about 117.3 rainy days.

\section{Land use and cropping pattern}

The total available land for utilization in the district is 280.4 thousand ha with a net sown area of 6894.19 ha (DSHB, 2009-10). Gross cropped area is 7,141.04 ha and cropping intensity is $104.0 \%$. The total cultivated area is divided in to three types i.e. upland, medium land and low land. Major field crops grown in the district are vegetable, rice, maize, ginger, sweet potato and turmeric (Table 1).

In kharif, rice, maize, green gram, black gram, arhar, ground nut, ginger, turmeric, sweet potato, tapioca and off season vegetables are generally grown and in rabi, crops like green gram, black gram, ground nut, mustard and vegetable crops are taken. Less number of crops are cultivated in rabi 
season in these islands due to severe water scarcity and lesser availability of soil moisture (Nanda et al., 2019). Among all the crops, vegetables cover the highest area of 1317 ha followed by rice ( $216 \mathrm{ha}$ ), maize (55 ha), ginger (51.5 ha), sweet potato (46 ha), tapioca (26.5 ha), turmeric (19.5 ha), green gram and black gram (13.7 ha). Ginger, turmeric and tapioca are the crops that are cultivated in these islands due to the climate suitability and more liked by the farmers due to lesser cost of cultivation and more net return (Nanda et al., 2018a). The prevailing cropping pattern and productivity scenario of South Andaman district is given in Table 2.

The past land uses data reveals that the area under cultivation is continuously increasing by converting the fallow land and other uncultivated land to culturable land whereas the area under forest is not much affected. The growing demand for food grain production due to increase in population is a major factor towards it.

\section{Food requirement}

Considering the decadal growth rate of $14.23 \%$ during 2001 to 2011 , the projected population of all the inhabited islands under South Andaman district for 2021 was estimated from the population of 2011. The present scenario of requirement of deficit food grains due to rising population in the study area is met by importing the food grain materials by ship from mainland India, which creates high selling price for the consumers and creates imbalance between demand and supply at many times due to uncertainty of ship sailing schedule.

Recommended dietary allowance (RDA) for adult Indian male and female and infants as suggested by the National Institute of Nutrition (Table 3 and Table 4), (Dietary Guidelines For Indians - A Manual, National Institute of Nutrition, Indian Council of
Medical Research, Hyderabad, India) was followed to calculate the edible components of the four major food groups i.e. cereals, pulses, oilseeds and vegetables including tubers required for a projected population in 2021. From the total population, $31 \%$ are infants and $69 \%$ are adults, hence food requirement is calculated for both infants and adults. Out of total population, $40.08 \%$ are workers consisting of $80.1 \%$ male and $19.9 \%$ female and they were treated as heavy and others were treated as moderate diet consuming humans.

The requirement of edible portion of the individual food crops grown were calculated according to the local affinity as per the present level of production. The net production requirement and the gross production requirement were estimated considering the edible portion in the food grains and the requirements for seeds, feed and wastage, respectively as given in Table 5 .

\section{Results and Discussion}

\section{Projected population}

The total population of the district is $2,38,142$ consisting of 1,27,283 males and 1,10,859 females as per 2011 census. Out of the total population, $40.66 \%$ are workers and among the total workers, $80.1 \%$ are male and $19.9 \%$ are female. The present decadal growth rate is $14.23 \%$ and as per this, the projected population of the district in 2021 is $2,72,029$ comprising of 1,45,395 males and 1,26,634 females.

\section{Food grain requirement}

The prescribed guidelines of recommended dietary allowance (RDA) for Indians by National Institute of Nutrition, Hyderabad (NIN, 1998; NIN, 2011) is followed to estimate the annual food requirement of the district for the projected population and is 
given in Table 6. The net production requirement of the individual food grain is calculated based on the edible portion of the food items, and the gross production requirements are calculated considering the requirements of seeds, feed and wastage. The estimated net food grain requirement, net production requirement and gross production requirement as per recommended dietary allowance for men and women separately are given in Table 7. A comparative study between the food grain production in 2015-16 and required food grain 2021 is presented in
Figure 1. As evident from the figure, the requirement of food grain is much higher than the present level of production for all the food groups. At present the net food grain requirement for the present population also not able to meet from the production from the field crops being cultivated in these islands alone. The deficit food grains are being imported from the mainland India by the Andaman and Nicobar Administration. This puts a heavy pressure on the Government to meet the demand as of now.

Table.1 Land use pattern of the South Andaman district

\begin{tabular}{|c|l|c|}
\hline Sl. No. & Land use & Area, ha \\
\hline $\mathbf{1}$ & Total geographical area & 310600.00 \\
\hline $\mathbf{2}$ & Reporting area for land utilization & 280442.46 \\
\hline $\mathbf{3}$ & Forest area & 267294.00 \\
\hline $\mathbf{4}$ & Not available for cultivation & 2729.48 \\
\hline $\mathbf{5}$ & Current fallow & 342.75 \\
\hline $\mathbf{6}$ & Other uncultivated land excluding fallow land & 1860.98 \\
\hline $\mathbf{7}$ & Fallow land other than current fallows & 1321.06 \\
\hline $\mathbf{8}$ & Net area sown & 6894.19 \\
\hline $\mathbf{9}$ & Area available for cultivation & 10418.98 \\
\hline
\end{tabular}

Source: DSHB, 2009-10

Table.2 Prevailing crops and their productivity scenario in South Andaman district

\begin{tabular}{|c|l|c|c|c|}
\hline S1. No. & Crops & Cultivated Area, ha & $\begin{array}{c}\text { Percent of total } \\
\text { cultivated area }\end{array}$ & Yield, q/ha \\
\hline $\mathbf{1}$ & Rice & 216.1 & 12.36 & 30.46 \\
\hline $\mathbf{2}$ & Maize & 55.0 & 3.15 & 20.27 \\
\hline $\mathbf{3}$ & Green gram & 7.2 & 0.41 & 3.13 \\
\hline $\mathbf{4}$ & Black gram & 6.5 & 0.37 & 2.77 \\
\hline $\mathbf{5}$ & Arhar & 0.5 & 0.03 & 4.00 \\
\hline $\mathbf{6}$ & Ground nut & 1.2 & 0.07 & 5.00 \\
\hline $\mathbf{7}$ & Mustard & 0.8 & 0.05 & 8.13 \\
\hline $\mathbf{8}$ & Ginger & 51.5 & 2.95 & 84.99 \\
\hline $\mathbf{9}$ & Turmeric & 19.5 & 1.12 & 66.46 \\
\hline $\mathbf{1 0}$ & Sweet Potato & 46.0 & 2.63 & 96.74 \\
\hline $\mathbf{1 1}$ & Tapioca & 26.5 & 1.52 & 273.58 \\
\hline $\mathbf{1 2}$ & Vegetables & 1317.0 & 75.35 & 64.16 \\
\hline
\end{tabular}

Source: DSHB, 2015-16 
Table.3 Recommended Dietary Allowance (RDA) for Indian adult male and female

\begin{tabular}{|c|c|c|c|c|c|c|c|c|c|c|}
\hline \multirow{4}{*}{$\begin{array}{l}\text { Sl. } \\
\text { No. }\end{array}$} & \multirow[t]{4}{*}{ Food groups } & \multirow{4}{*}{$\begin{array}{c}\text { gm/ } \\
\text { portion }\end{array}$} & \multicolumn{8}{|c|}{ Recommended Dietary Allowance } \\
\hline & & & \multicolumn{4}{|c|}{ Moderate } & \multicolumn{4}{|c|}{ Heavy } \\
\hline & & & \multicolumn{2}{|c|}{ Male } & \multicolumn{2}{|c|}{ Female } & \multicolumn{2}{|c|}{ Male } & \multicolumn{2}{|c|}{ Female } \\
\hline & & & $\begin{array}{l}\text { Nos. of } \\
\text { portions }\end{array}$ & $\begin{array}{l}\text { Gm } \\
\text { per } \\
\text { day }\end{array}$ & $\begin{array}{l}\text { Nos. of } \\
\text { portions }\end{array}$ & $\begin{array}{l}\text { gm } \\
\text { per } \\
\text { day }\end{array}$ & $\begin{array}{l}\text { Nos. of } \\
\text { portions }\end{array}$ & $\begin{array}{l}\text { gm } \\
\text { per } \\
\text { day }\end{array}$ & $\begin{array}{l}\text { Nos. of } \\
\text { portions }\end{array}$ & $\begin{array}{l}\text { gm } \\
\text { per } \\
\text { day }\end{array}$ \\
\hline $\mathbf{1}$ & $\begin{array}{l}\text { Cereals and } \\
\text { millets }\end{array}$ & 30 & 15 & 450 & 11 & 330 & 20 & 600 & 16 & 80 \\
\hline 2 & Pulses & 30 & 3 & 90 & 2.5 & 75 & 4 & 120 & 3 & 90 \\
\hline 3 & Fats and oils & 5 & 6 & 30 & 5 & 25 & 8 & 40 & 6 & 30 \\
\hline 4 & $\begin{array}{l}\text { Roots and } \\
\text { tubers }\end{array}$ & 100 & 2 & 200 & 2 & 200 & 2 & 200 & 2 & 200 \\
\hline 5 & $\begin{array}{l}\text { Green leafy } \\
\text { vegetables }\end{array}$ & 100 & 1 & 100 & 1 & 100 & 1 & 100 & 1 & 100 \\
\hline 6 & $\begin{array}{l}\text { Other } \\
\text { vegetables }\end{array}$ & 100 & 2 & 200 & 2 & 200 & 2 & 200 & 2 & 200 \\
\hline
\end{tabular}

Source: http://www.ninindia.org/DietaryguidelinesforIndians-Finaldraft.pdf (Dietary Guidelines For Indians - A Manual, National Institute of Nutrition, Indian Council of Medical Research, Hyderabad, India)

Table.4 Recommended dietary allowance (RDA) for Indian infants

\begin{tabular}{|c|c|c|c|c|c|c|c|c|c|c|c|c|c|}
\hline \multirow{3}{*}{$\begin{array}{l}\text { Sl. } \\
\text { No. }\end{array}$} & \multirow[t]{3}{*}{ Food groups } & \multirow{3}{*}{$\underset{\text { portion }}{\text { gm }}$} & \multicolumn{11}{|c|}{ Recommended Dietary Allowance (Nos. of portions) for infants } \\
\hline & & & \multirow[t]{2}{*}{$\begin{array}{c}\text { 6-12 } \\
\text { months }\end{array}$} & \multirow[t]{2}{*}{$\begin{array}{c}1-3 \\
\text { years }\end{array}$} & \multirow[t]{2}{*}{$\begin{array}{c}4-6 \\
\text { years }\end{array}$} & \multirow[t]{2}{*}{$\begin{array}{c}7-9 \\
\text { years }\end{array}$} & \multicolumn{2}{|c|}{$\begin{array}{l}10-12 \\
\text { Years }\end{array}$} & \multicolumn{2}{|c|}{$\begin{array}{l}13-15 \\
\text { years }\end{array}$} & \multicolumn{2}{|c|}{$\begin{array}{l}16-18 \\
\text { years }\end{array}$} & \multirow[t]{2}{*}{ Avg } \\
\hline & & & & & & & $\mathrm{F}$ & $\mathrm{M}$ & $\mathrm{F}$ & M & $\mathrm{F}$ & M & \\
\hline 1 & $\begin{array}{l}\text { Cereals and } \\
\text { millets }\end{array}$ & 30 & 0.5 & 2 & 4 & 6 & 8 & 10 & 11 & 14 & 11 & 15 & 6.7 \\
\hline 2 & Pulses & 30 & 0.25 & 1 & 1 & 2 & 2 & 2 & 2 & 2.5 & 2.5 & 3 & 1.6 \\
\hline 3 & Fats and oils & 5 & 4 & 5 & 5 & 5 & 5 & 5 & 5 & 5 & 5 & 5 & 6.3 \\
\hline 4 & $\begin{array}{l}\text { Roots and } \\
\text { tubers }\end{array}$ & 100 & 0.5 & 0.5 & 1 & 1 & 1 & 1 & 1 & 1.5 & 2 & 2 & 1 \\
\hline 5 & $\begin{array}{l}\text { Green leafy } \\
\text { vegetables }\end{array}$ & 100 & 0.25 & 0.5 & 0.5 & 1 & 1 & 1 & 1 & 1 & 1 & 1 & 0.8 \\
\hline 6 & $\begin{array}{l}\text { Other } \\
\text { vegetables }\end{array}$ & 100 & 0.25 & 0.5 & 1 & 1 & 2 & 2 & 2 & 2 & 2 & 2 & 1.3 \\
\hline
\end{tabular}


Table.5 Edible portion, local affinity and requirement towards seed, feed and losses of food items

\begin{tabular}{|l|l|c|c|c|}
\hline $\begin{array}{l}\text { SI. } \\
\text { No. }\end{array}$ & Food items & $\begin{array}{c}\text { Edible portion } \\
\text { (\% of whole grain) }\end{array}$ & $\begin{array}{c}\text { Local affinity (\% } \\
\text { of food group) }\end{array}$ & $\begin{array}{c}\text { Requirement towards seed, feed } \\
\text { and wastage (\% of gross } \\
\text { production) }\end{array}$ \\
\hline & Cereals & & & \\
\hline $\mathbf{1}$ & Rice & 66 & 80 & 22 \\
\hline $\mathbf{2}$ & Maize & 78 & 20 & 22 \\
\hline & Pulses & & & 30 \\
\hline $\mathbf{3}$ & Green gram & 70 & 51 & 30 \\
\hline $\mathbf{4}$ & Black gram & 70 & 46 & \\
\hline $\mathbf{5}$ & Arhar & 70 & 3 & 25 \\
\hline & Oilseeds & & & \\
\hline $\mathbf{6}$ & Groundnut & 28 & 36 & 20 \\
\hline $\mathbf{7}$ & Mustard & 33 & 64 & 20 \\
\hline & Tuber crops and vegetables & & \\
\hline $\mathbf{8}$ & Sweet potato & 100 & 63 & 20 \\
\hline $\mathbf{9}$ & Tapioca & 100 & 37 & \\
\hline $\mathbf{1 0}$ & Vegetables & 100 & 100 & \\
\hline
\end{tabular}

Table.6 Food group wise production requirement as per RDA for the projected population of South Andaman district during 2021

\begin{tabular}{|c|l|c|c|c|}
\hline $\begin{array}{r}\text { Sl. } \\
\text { No. }\end{array}$ & Food groups & $\begin{array}{c}\text { Net food requirement } \\
\text { (Tonnes) }\end{array}$ & $\begin{array}{c}\text { Net production } \\
\text { requirement } \\
\text { (Tonnes) }\end{array}$ & $\begin{array}{c}\text { Gross production } \\
\text { requirement (Tonnes) }\end{array}$ \\
\hline $\mathbf{1}$ & Rice & 31338 & 47481 & 60873 \\
\hline $\mathbf{2}$ & Maize & 7834 & 10044 & 12877 \\
\hline & Cereals & $\mathbf{3 9 1 7 2}$ & $\mathbf{5 7 5 2 5}$ & $\mathbf{7 3 7 5 0}$ \\
\hline $\mathbf{3}$ & Green gram & 4125 & 5893 & 8418 \\
\hline $\mathbf{4}$ & Black gram & 3720 & 5315 & 7593 \\
\hline $\mathbf{5}$ & Arhar & 243 & 347 & 495 \\
\hline & Pulses & $\mathbf{8 0 8 8}$ & $\mathbf{1 1 5 5 5}$ & $\mathbf{1 6 5 0 6}$ \\
\hline $\mathbf{6}$ & Ground nut & 1901 & 6791 & 9054 \\
\hline $\mathbf{7}$ & Mustard & 1268 & 3841 & 5122 \\
\hline & Oil seeds & $\mathbf{3 1 6 9}$ & $\mathbf{1 0 6 3 2}$ & $\mathbf{1 4 1 7 6}$ \\
\hline $\mathbf{8}$ & Vegetable & 26709 & 26709 & 33386 \\
\hline $\mathbf{9}$ & Sweet potato & 10641 & 10641 & 13301 \\
\hline $\mathbf{1 0}$ & Tapioca & 6249 & 6249 & 7812 \\
\hline & Vegetables and tubers & $\mathbf{4 3 5 9 9}$ & $\mathbf{4 3 5 9 9}$ & $\mathbf{5 4 4 9 9}$ \\
\hline & Total & $\mathbf{9 4 0 2 8}$ & $\mathbf{1 2 3 3 1 1}$ & $\mathbf{1 5 8 9 3 1}$ \\
\hline
\end{tabular}


Table.7 Requirement of food materials as per recommended dietary allowance for the projected population of South Andaman district during 2021

\begin{tabular}{|c|c|c|c|c|c|c|c|c|c|c|c|c|}
\hline \multirow[t]{2}{*}{$\begin{array}{l}\text { Sl. } \\
\text { No. }\end{array}$} & \multirow[t]{2}{*}{ Category } & \multirow{2}{*}{$\begin{array}{c}\text { Population } \\
\text { as per } \\
2011 \\
\text { census }\end{array}$} & \multirow{2}{*}{$\begin{array}{c}\text { Projected } \\
\text { population } \\
\text { in } 2021\end{array}$} & \multirow{2}{*}{$\begin{array}{l}\text { Projected } \\
\text { infant } \\
\text { population } \\
\text { in } 2021\end{array}$} & \multirow{2}{*}{$\begin{array}{l}\text { Projected } \\
\text { adult } \\
\text { population } \\
\text { in } 2021\end{array}$} & \multirow{2}{*}{$\begin{array}{l}\text { Projected } \\
\text { workers } \\
\text { population } \\
\text { in } 2021\end{array}$} & \multirow{2}{*}{$\begin{array}{l}\text { Projected } \\
\text { others } \\
\text { population } \\
\text { in } 2021\end{array}$} & \multicolumn{4}{|c|}{$\begin{array}{l}\text { Projected annual net food requirement } \\
\text { in 2021, Tonnes }\end{array}$} & \multirow[t]{2}{*}{ Remarks } \\
\hline & & & & & & & & $\begin{array}{c}\text { Cereals } \\
\text { and } \\
\text { millets }\end{array}$ & Pulses & $\begin{array}{l}\text { Fats } \\
\text { and } \\
\text { oils }\end{array}$ & $\begin{array}{l}\text { Vegetables } \\
\text { and } \\
\text { tubers/roots }\end{array}$ & \\
\hline 1 & Male & 127283 & 145395 & 45072 & 100323 & 58274 & 42049 & 22982 & 4727 & 1828 & 23303 & \multirow{3}{*}{$\begin{array}{l}\text { Workers taken as } \\
\text { heavy and others } \\
\text { taken as moderate } \\
\text { for calculation of } \\
\text { food requirement }\end{array}$} \\
\hline 2 & Female & 110859 & 126634 & 39257 & 87377 & 50755 & 36622 & 16190 & 3361 & 1340 & 20296 & \\
\hline & Total & 238142 & 272029 & 84329 & 187700 & 109029 & 78671 & 39172 & 8088 & 3168 & 43599 & \\
\hline
\end{tabular}

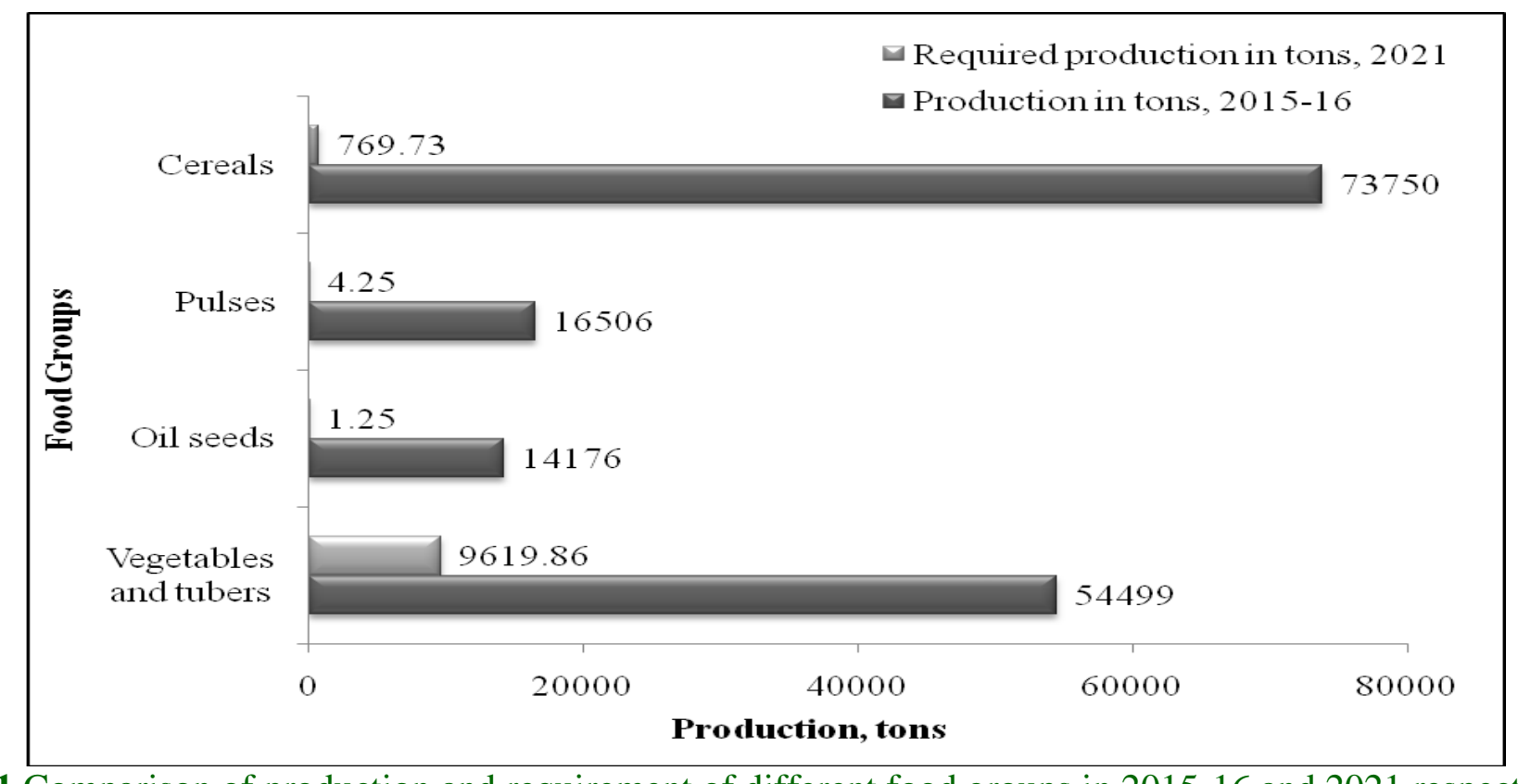

Fig.1 Comparison of production and requirement of different food groups in 2015-16 and 2021 respectively 
With rise in population at a rate of $14.23 \%$ as decadal growth rate, the production level for all the crops need to be improved. Being isolated from the mainland India and with the fragile island ecosystem, for these islands it is nearly impossible to meet the food grain requirement from the projected population.

But with improved agricultural practice, introduction of high yielding varieties and bringing more areas to cultivation can able to meet a large percent of the food grain production.

The annual food requirement of the South Andaman district comprising of 10 inhabited islands for the projected population of $2,72,029$ for the year 2021 was estimated to be 73,750 tonnes of cereals, 16,506 tonnes of pulses, 14,176 tonnes of oil seeds and 54,499 tonness of vegetables and tubers. To meet the food grain requirement improved agricultural practice, introduction of high yielding varieties and bringing more areas to cultivation are the policies need to be adopted by the policy makers and other stake holder so that food security can be achieved in these group of islands.

\section{Acknowledgement}

The authors of the manuscript are highly thankful to Director, ICAR-Central Island Agricultural Research Institute, Port Blair for sanction of the study leave to carry out the research work.

\section{References}

DSHB. 2015-16. District Statistical Hand Book, Directorate of Economics and Statistics, Andaman and Nicobar Administration Port Blair.

DSHB. 2009-10. District Statistical Hand Book, Directorate of Economics and Statistics, Andaman and Nicobar
Administration Port Blair.

Gadgil, S. 1996. Climate change and agriculture - an Indian perspective. In Climate Variability and Agriculture, Abrol, Y.R., Gadgil, S., Pant, G.B. (eds). Narosa: New Delhi, 1-18.

Gadgil, S. and Rupa Kumar, K. 2006. The Asian monsoon - agriculture and economy. In The Asian Monsoon, Wang, B. (ed). Springer Praxis: UK 651-683.

Government of India, 2018-19. Third advance estimates of production of food grains for 2018-19. Agricultural Statistics Division, Directorate of Economics and Statistics, Department of Agriculture Cooperation and Farmers Welfare, New Delhi, India

ICAR-CIARI, 2017. Annual Report 2016-17. ICAR-Central Island Agricultural Research Institute, Post Box No. 181, Port Blair, Andaman and Nicobar Group of Islands, India. 265p

ICAR-KVK, 2018. Annual Report 2017-18. ICAR-Krishi Vigyan Kendra, Port Blair, Andaman and Nicobar Group of Islands, India. 118p

Kumar, K. Krishna, Kumar, K. Rupa, Ashrit, R. G., Deshpande, N. R. and Hansen, J. W. 2004. Climate impacts on Indian agriculture. International Journal of Climatology, 24: 1375-1393.

Maurya, G. P., Kumar, Santosh and Sen, C. 2016. Impact of climate change on food grain productivity in Mirzapur district of Uttar Pradesh. International Journal of Agriculture Sciences, 8(55): 30333034.

Nanda, B.K., Sahoo, N. and Panigrahi, B. 2018a. Agro climatic conditions, cropping pattern and its profitability in South Andaman district of bay islands. Journal of Krishi Vigyan, 7(1): 4-9.

Nanda, B.K., Sahoo, N., Panigrahi, B. and Paul, J.C. 2018b. Assessment of fresh water resources for effective crop 
planning in South Andaman district. Journal of Krishi Vigyan, 7(Special Issue): 6-11.

Nanda, B.K., Sahoo, N. and Panigrahi, B. 2019. Assessment of soil loss from agricultural lands of South Andaman district in tropical islands. International Journal of Current Microbiology and Applied Sciences. 8(3): 2190-2198.

NIN, 1998. Report of working group on dietary Guidelines for Indians. National Institute of Nutrition, Indian Council of Medical Research, Hyderabad, India.

NIN, 2011. Dietary Guidelines for Indians A Manual. National Institute of Nutrition, Indian Council of Medical Research, Hyderabad, India.

Parthasarathy, B., Rupa Kumar, K. and Munot, A. A. 1992. Forecast of rainy season food grain production based on monsoon rainfall. Indian Journal of
Agricultural Sciences 62: 1-8.

Patel, N. and Rajput, T. B. S. 2015. Micro irrigation technology for sustainable agricultural production - a success story from semi arid regions of India. NDCWWC Journal (A half yearly journal of New Delhi Centre of World Water Council), 4(2): 27-31.

Ray, S. and Bhattacharyya, B. 2018. Statistical investigation of food grains demand and supply in India. International Journal of Agriculture Sciences, 10(11): 6200-6205.

Webster, P. J., Magana, V. O., Palmer, T. N., Shukla, J., Thomas, R. A., Yanai, M., Yasunari, T. 1998. Monsoons: processes, predictability and the prospects of prediction. Journal of Geophysical Research, 103: 1445114510.

\section{How to cite this article:}

Nanda, B. K., N. Sahoo and Panigrahi, B. 2020. Assessment of Nutritional Requirement for Food Security in Tropical Islands of India. Int.J.Curr.Microbiol.App.Sci. 9(04): 1120-1128. doi: https://doi.org/10.20546/ijcmas.2020.904.133 